\title{
COMPARATIVE STUDY OF EFFECT OF CHAIN YOGIC EXERCISE (YOGASANA) AND YOGIC THERAPY (AGNISAR KRIYA) FOR REHABILITATION OF TYPE 2 DIABETES MELLITUS (T2D)
}

\author{
Amit Chandra Deshmukh ${ }^{1 i}$, \\ Li Youqiang ${ }^{2}$ \\ 1Doctoral Student, Shanghai University of Sport, \\ Department of Physical Education, Sports Coaching \& Training, \\ Shanghai, China \\ ${ }^{2}$ Professor, Shanghai University of Sport, \\ Department of Physical Education, Sports Coaching \& Training, \\ Shanghai, China
}

\begin{abstract}
:
The motive of this study was to find out the effect of Chain Yogic Exercise (Yogasana), Yogic Therapy (Agnisar Kriya) on Diabetes Mellitus (T2D). For the purpose of this study 200 subjects were selected and divided into two groups from Delhi, India. Both groups are experimental groups. In each group, 100:100 Type 2 Diabetes Mellitus (T2DM) subjects were distributed. There were 50 females and 50 males in each group i.e. half of the each group was female. The subjects' age ranged between 35-45 years. One group was engaged in Chain Yogic Exercise (Yogasana) and the other group was perform Yogic Therapy (Agnisar Kriya), This process was for 90 days (30-30-30 days). The data was collected on the first day (dated $16^{\text {th }}$ September 2020) of $1^{\text {st }}$ round as pre-test and on the last day (dated $16^{\text {th }}$ October 2020) of $1^{\text {st }}$ round as post-test. For statistical analysis and interpretation of data, paired t-Test was employed. The level of significance had been taken 0.05 and 0.01. The study found Chain Yogic Exercise (Yogasana), Yogic Therapy (Agnisar Kriya) both has a significant effect to control Diabetes Mellitus (T2D). The study also found that Yogic Therapy (Agnisar Kriya) had much better effect to control Diabetes Mellitus (T2D) than Chain Yogic Exercise (Yogasana).
\end{abstract}

Keywords: Chain Yogic Exercise (Yogasana), Yogic Therapy (Agnisar Kriya), Diabetes Mellitus (T2D)

i Correspondence: email deshmukh.chandra@gmail.com, youmecity@163.com 


\section{Introduction}

Man is in constant search for health, happiness and peace, because health is the key to success and salvation. The purpose of practicing yoga is to harmonize the body, mind and soul so that they function in full form. Diabetes is considering a slow killer affecting the majority of the population in different age groups in the world. This is seed more in the civilized society. This is due to modernization, fast life, stressful life, inappropriate diet, weak and imbalanced metabolism etc. Squall Yogasanas called Chain Yogic Exercise (Yogasana). In the other way we can say the loop of the yogasans called Chain Yogasans. Anyone doing Yogasanas 'one by one' in a 'continual flow' or 'rhythm'; specified or recommended by the experts called Chain Yogic Exercise (Yogasana). Yogic Therapy (Agnisar Kriya) is a technique of Yoga Cleaning (Part of Shatkarma) which is believed to clear the chakra of manipura (navel) as well as strengthen the muscles of the abdomen and boost digestion. The Sanskrit name comes from agni, meaning 'fire'; sar, meaning 'essence'; and kriya, meaning 'action'. Type 2 diabetes (T2D) starts with insulin resistance, a disorder in which cells fail to respond properly to insulin. A lack of insulin can also evolve as the illness progresses. Previously, this type was referred to as "non-insulin dependent diabetes mellitus" (NIDDM) or 'adult-onset diabetes'. A combination of excessive body weight and inadequate exercise is the most common cause. "Better health is central to human happiness and well-being" [1] (Hande Genc, 2018). "It also makes an important contribution to economic progress, as healthy populations live longer, are more productive, and save more" (Mahaveer Golechha, 2015) [2]. Many variables affect health status and a nation's capability to provide best health services for its citizens. "Health ministries are playing an important character and other governmental departments, civil society's groups, NGOs, donor organizations and social bodies themselves" [3].

\section{Methods}

For the purpose of this study 200 subjects were selected and divided into two groups from Delhi, India. Both groups were experimental groups. In each group, 100:100 Type 2 Diabetes Mellitus (T2DM) subjects were distributed. There were 50 females and 50 males in each group i.e. half of the each group was female. The subjects' age ranged between 35-45 years. One group was engaged in Chain Yogic Exercise (Yogasana) and the other group was perform Yogic Therapy (Agnisar Kriya), this process was for 90 days (30-3030 days). The data was collected on the first day (dated $16^{\text {th }}$ September 2020) of $1^{\text {st }}$ round as pre-test and on the last day (dated $16^{\text {th }}$ October 2020) of $1^{\text {st }}$ round as post-test. The posttest data of $1^{\text {st }}$ round was the pre-test data for $2^{\text {nd }}$ round. Blood Sugar Level and general well-being samples have been taken before starting the experiment, which called pre-test data. After 30 days of practice, blood sugar level and well-being facts have been taken again, which called post-test data for pre-test and post-test data such a way will proceed for the next 30 days (30:30:30 days). For statistical analysis and interpretation of data, paired $t$-Test was employed. The level of significance had been taken 0.05 and 0.01 . 


\section{Results}

Table 1: Comparing Mean Data BGL (Blood Glucose Level) of Group One

\begin{tabular}{|c|l|c|c|c|c|}
\hline \multirow{2}{*}{$\begin{array}{c}\text { Sr. } \\
\text { No. }\end{array}$} & \multirow{2}{*}{$\begin{array}{l}\text { Data Collection } \\
\text { Frequency }\end{array}$} & $\begin{array}{c}\text { Fasting } \\
\mathbf{m g} / \mathbf{d L}\end{array}$ & $\begin{array}{c}\text { PP 2:00 Hr. } \\
\mathbf{m g} / \mathbf{d L}\end{array}$ & $\begin{array}{c}\text { PP 2:30 Hr } \\
\mathbf{m g} / \mathbf{d L}\end{array}$ & $\begin{array}{c}\text { PP 3:00 Hr } \\
\mathbf{~ m g / d L}\end{array}$ \\
\hline 1 & Pre-Data & 136.22 & 253.06 & 228.26 & 216.67 \\
\hline 2 & After 30 Days & 131.42 & 242.05 & 219.35 & 209.03 \\
\hline 3 & After 60 Days & 128.29 & 231.42 & 214.17 & 199.64 \\
\hline 4 & Final Post Data & 110.69 & 195.00 & 175.70 & 158.77 \\
\hline
\end{tabular}

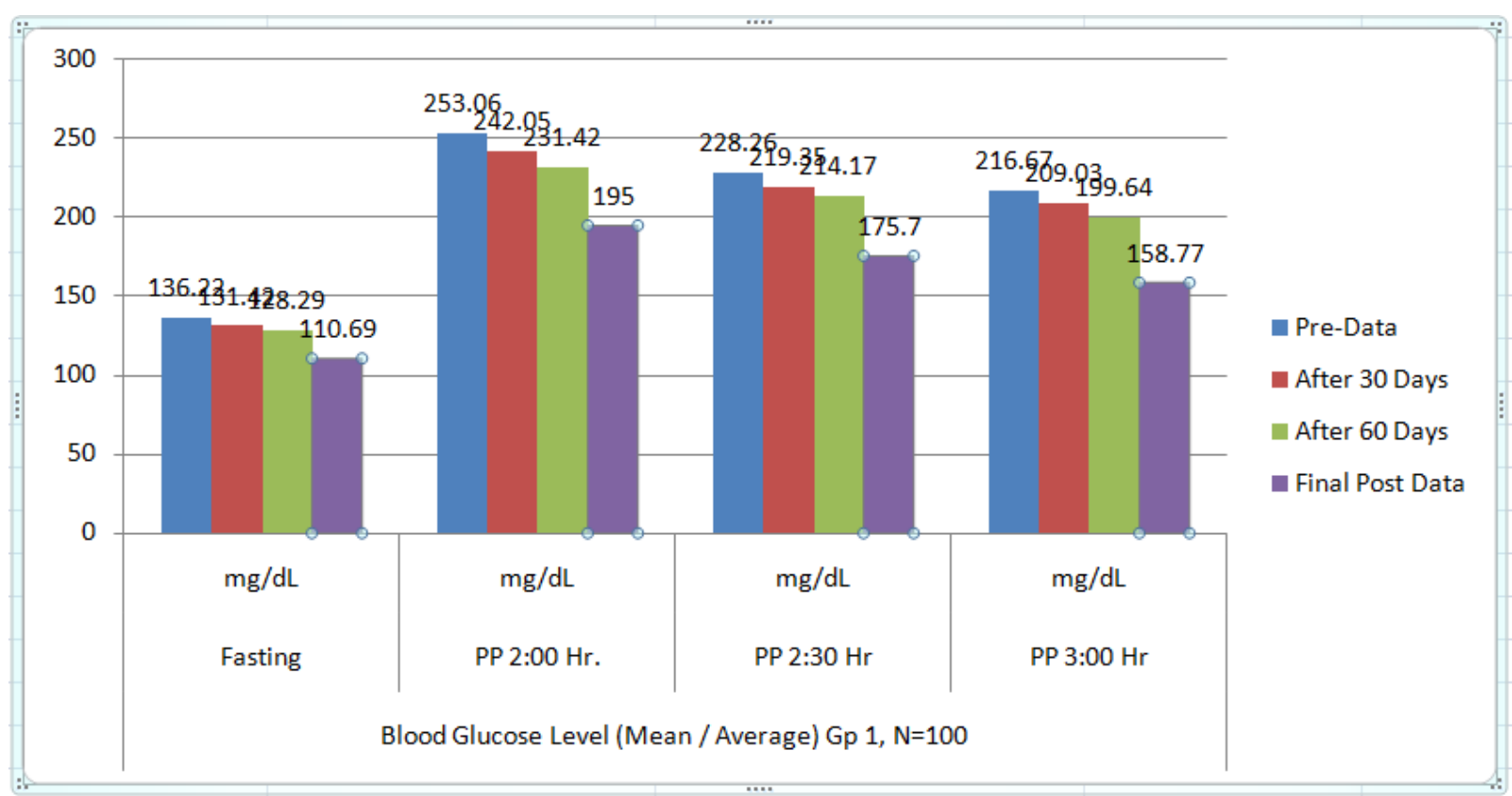

Figure 1: Comparing Average Data of BGL of Group one

Table 1 shows that Fasting Blood Glucose Level (BGL) is continuously down i.e. $136.22>131.42>128.29>110.69$. Hence, here BGL is down $136.22 \mathrm{mg} / \mathrm{dL}$ to $110.69 \mathrm{mg} / \mathrm{dL}$, the difference is 25.53 . In percentage, we can say that $18.74 \%$ befit by the Chain Yogic Exercise (Yogasana) to the Group one after practice of 90 days.

Table 2: Comparing Mean Data BGL (Blood Glucose Level) of Group 2

\begin{tabular}{|c|c|c|c|c|c|}
\hline \multirow[b]{2}{*}{$\begin{array}{l}\text { Sr. } \\
\text { No. }\end{array}$} & \multirow{2}{*}{$\begin{array}{l}\text { Data Collection } \\
\text { Frequency }\end{array}$} & \multicolumn{4}{|c|}{ Blood Glucose Level (Mean / Average) Gp 2, N=100 } \\
\hline & & $\begin{array}{l}\text { Fasting } \\
\mathrm{mg} / \mathrm{dL}\end{array}$ & $\begin{array}{c}\text { PP 2:00 Hr. } \\
\text { mg/dL }\end{array}$ & $\begin{array}{c}\text { PP 2:30 Hr } \\
\text { mg/dL }\end{array}$ & $\begin{array}{c}\text { PP 3:00 Hr } \\
\text { mg/dL }\end{array}$ \\
\hline 1 & Pre-Data & 134.84 & 248.30 & 229.35 & 215.10 \\
\hline 2 & After 30 Days & 131.47 & 242.63 & 222.54 & 204.25 \\
\hline 3 & After 60 Days & 129.05 & 236.69 & 215.07 & 200.55 \\
\hline 4 & Final Post Data & 117.62 & 215.58 & 194.25 & 185.50 \\
\hline
\end{tabular}

Table 2 shows that Fasting Blood Glucose Level (BGL) is continuously reduce i.e. 134.84 $>131.47>129.05>117.62$, PP 2:00 hr Blood Glucose Level (BGL) reduces as 248.30>242.63 
$>236.69>215.58 \mathrm{mg} / \mathrm{dL}$, PP 2:30 hr Blood Glucose Level (BGL) reduces as 229.35> 222.54 $>215.07>194.25$, PP 3:00 hr Blood Glucose Level (BGL) reduces as 215.10> 204.25> 200.55 $>185.50$. Hence, here BGL is down $134.84 \mathrm{mg} / \mathrm{dL}$ to $117.62 \mathrm{mg} / \mathrm{dL}$, the difference is 17.22. In percentage, we can say that $12.77 \%$ befit in fasting blood glucose level by the Yogic Therapy (Agnisar Kriya) to the Group two after practice of 90 days and $13.18 \%$ befit in PP 2:00 hr blood glucose level by the Yogic Therapy (Agnisar Kriya) to the Group two after practice of 90 days.

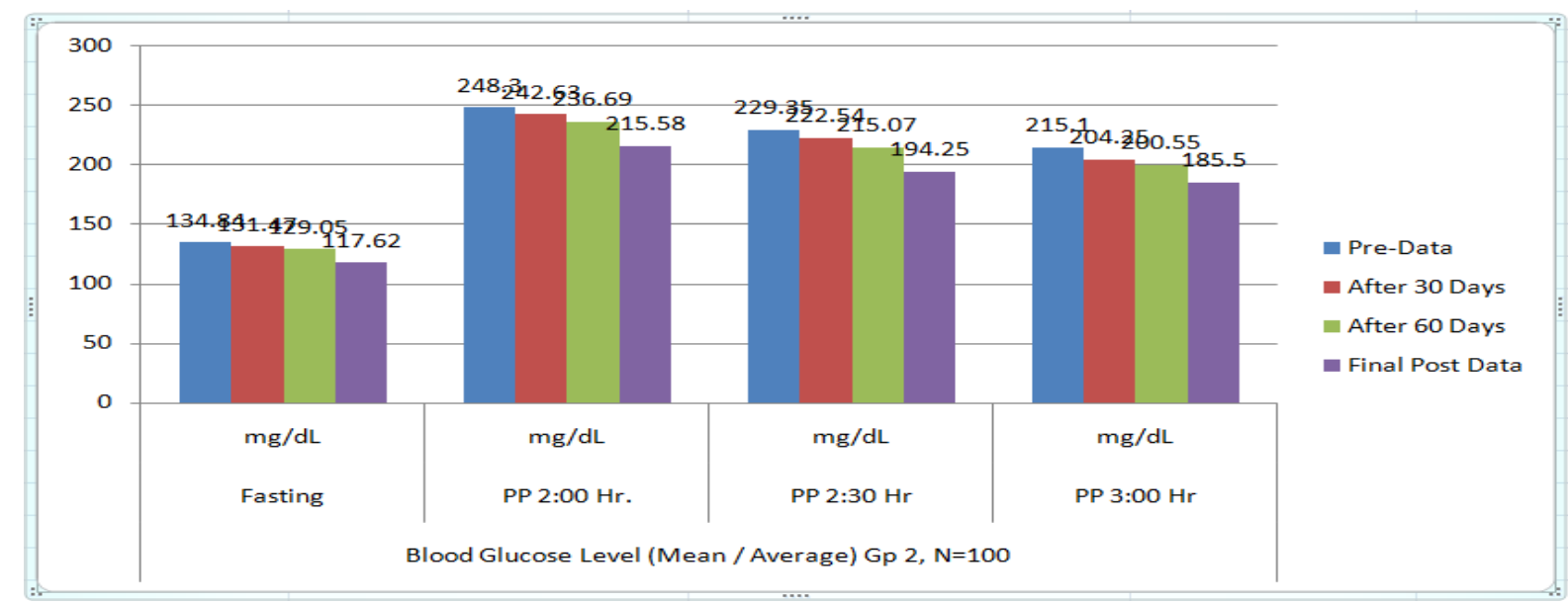

Figure 2: Comparing Average Data of BGL of Group two

Table 3: Fasting Blood Glucose data of both groups

\begin{tabular}{|c|l|c|c|}
\hline \multirow{2}{*}{\begin{tabular}{c}
\multirow{2}{*}{ Sr. } \\
No.
\end{tabular}} & \multirow{2}{*}{ Data Frequency } & \multicolumn{2}{|c|}{$\begin{array}{c}\text { Mean Value Fasting Blood Glucose Level } \\
\text { mg/dL }\end{array}$} \\
\cline { 3 - 4 } & & Group 1 & Group 2 \\
\cline { 3 - 4 } & & $\mathbf{N = 1 0 0}$ & $\mathbf{N = 1 0 0}$ \\
\hline 1 & Pre-Data & 136.22 & 134.84 \\
\hline 2 & After 30 Days & 131.42 & 131.47 \\
\hline 3 & After 60 Days & 128.29 & 129.05 \\
\hline 4 & Final Post Data & $\mathbf{1 1 0 . 6 9}$ & $\mathbf{1 1 7 . 6 2}$ \\
\hline
\end{tabular}

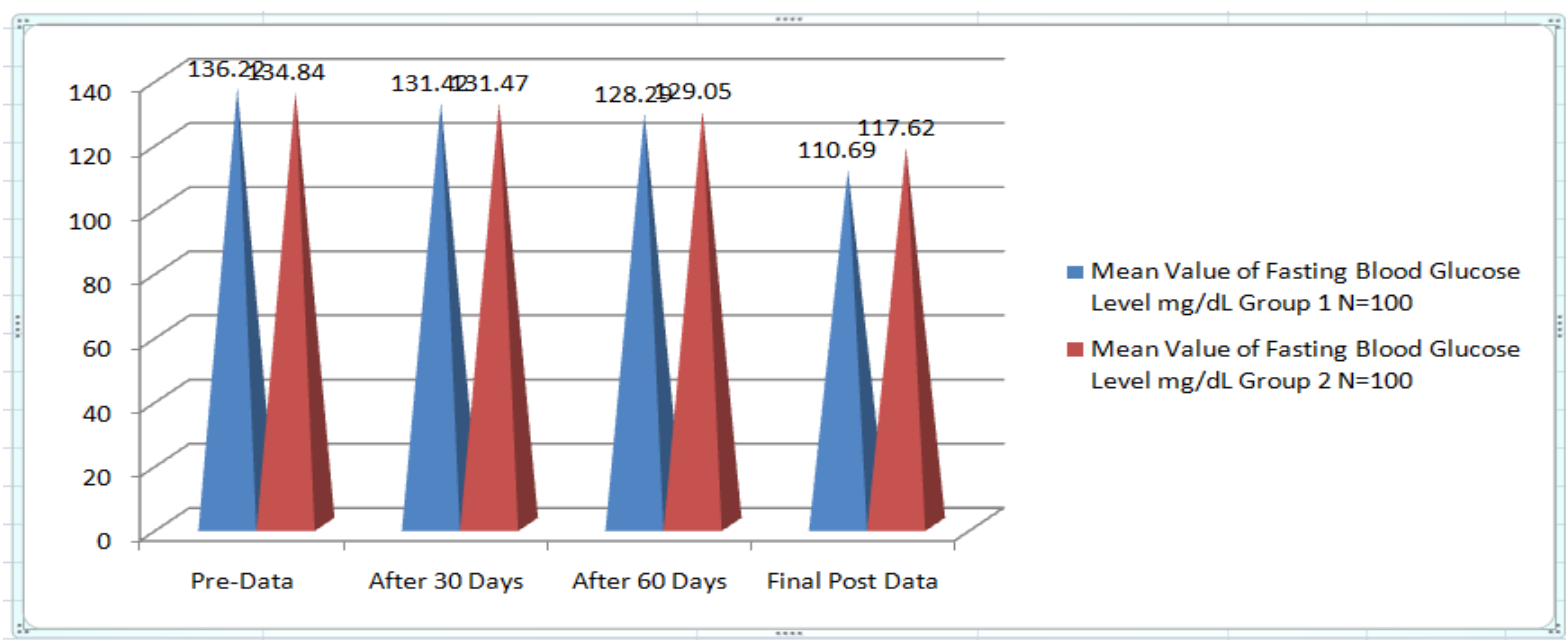

Figure 3: Mean Value Fasting Blood Glucose Level in mg/dL 
Table 4: Fasting Blood Glucose data for t-test of both groups

\begin{tabular}{|c|l|c|c|c|c|c|}
\hline $\begin{array}{c}\text { Sr. } \\
\text { No. }\end{array}$ & Groups & $\begin{array}{c}\text { Sample } \\
\text { N }\end{array}$ & $\begin{array}{c}\text { Mean of } \\
\text { Fasting BGL } \\
\mathbf{m g} / \text { dL } \\
\text { (After 90 Days) }\end{array}$ & SD & t-test & $\begin{array}{c}\text { Significant Level } \\
\text { based of ' } \mathbf{t}^{\prime} \\
\text { distribution list }\end{array}$ \\
\cline { 1 - 4 } 1 & Group 1 & 100 & 110.69 & 7.528659049 & \multirow{2}{*}{1.3537} & Not Significant* \\
\hline 2 & Group 2 & 100 & 117.62 & 9.130678668 & & \\
\hline
\end{tabular}

*Significant level at 0.05 level is $1.97 \&$ at 0.01 level is 2.60 .

Table 4 shows that t-test value is 1.3537, which is not greater then d.f. value of 198 in tdistribution list, at 0.05 level (value 1.97) and 0.01 level (value 2.60). So, we can say that both groups for fasting blood glucose level is not significant, this means Chain Yogic Exercise (Yogasana) and Yogic Therapy (Agnisar Kriya) both are good practices to control fasting blood glucose level.

Table 5: PP 2:00 hr Blood Glucose data of both groups

\begin{tabular}{|c|l|c|c|}
\hline \multirow{2}{*}{$\begin{array}{c}\text { Sr. } \\
\text { No. }\end{array}$} & \multirow{2}{*}{$\begin{array}{l}\text { Collection } \\
\text { Frequency }\end{array}$} & \multicolumn{2}{|c|}{$\begin{array}{r}\text { Mean Value of PP 2:00 Hr. Blood Glucose Level } \\
\text { mg/dL }\end{array}$} \\
\cline { 3 - 4 } & & Group 1 & Group 2 \\
\cline { 2 - 4 } & N=100 & 248.28 \\
\hline 1 & Pre-Data & 253.06 & 242.60 \\
\hline 2 & After 30 Days & 242.05 & 236.70 \\
\hline 3 & After 60 Days & 231.42 & 215.60 \\
\hline 4 & Final Post Data & 195.00 & \\
\hline
\end{tabular}

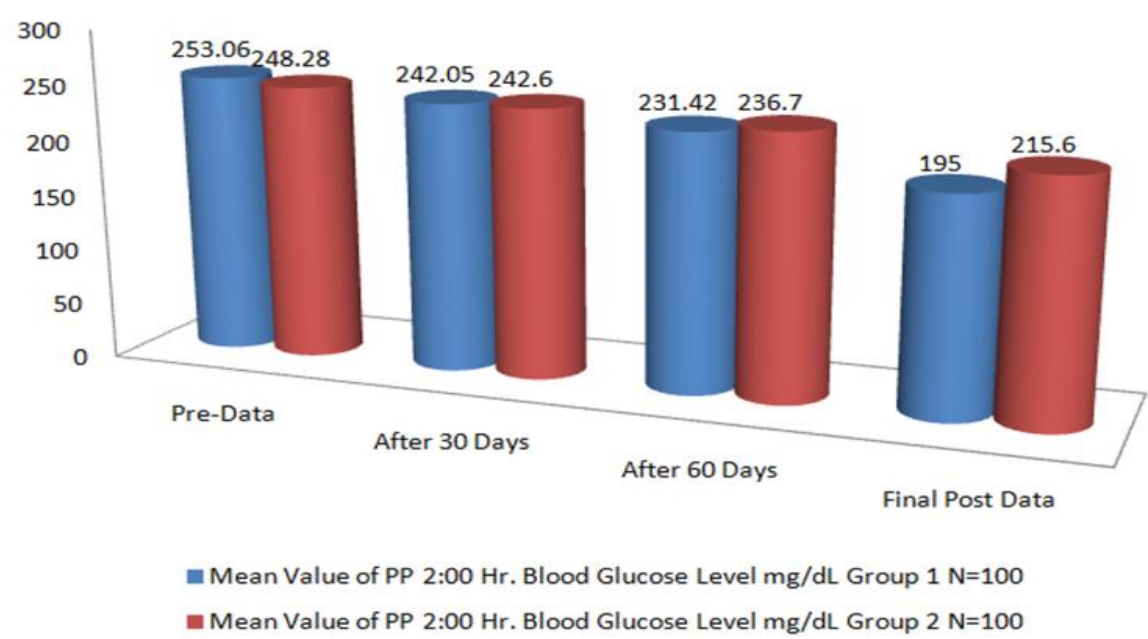

Figure 4: Mean Value of PP 2:00 Hr. Blood Glucose Level 
Table 6: PP 2:00 hr. Blood Glucose data for t-test of both groups

\begin{tabular}{|c|l|c|c|c|c|c|}
\hline $\begin{array}{c}\text { Sr. } \\
\text { No. }\end{array}$ & Groups & $\begin{array}{c}\text { Sample } \\
\mathbf{N}\end{array}$ & $\begin{array}{c}\text { Mean of } \\
\text { PP 2:00 Hr BGL } \\
\mathbf{m g} / \mathbf{d L} \\
\text { (After 90 Days) }\end{array}$ & SD & t-test & $\begin{array}{c}\text { Significant Level } \\
\text { based of 't' } \\
\text { distribution list }\end{array}$ \\
\hline 1 & Group 1 & 100 & 195.00 & 29.93427143 & \multirow{2}{*}{5.034969959} & Significant* \\
\hline 2 & Group 2 & 100 & 215.60 & 27.89054363 & & \\
\hline & & & $\mathrm{MD}=20.6$ & & & \\
\hline
\end{tabular}

*Significant level at 0.05 level is $1.97 \&$ at 0.01 levels is 2.60 .

Table 6 shows that t-test value is 5.035, which is greater than d.f. value of 198 in $t-$ distribution list, at 0.05 level (value 1.97) and 0.01 level (value 2.60). So, we can say that both groups for PP 2:00 hr blood glucose level is significant, this means 'Yogasana' and 'Agnisar Kriya' both are good practices to controlling fasting blood glucose, but Yogic Therapy (Agnisar Kriya) had much better effect to control Diabetes Mellitus (T2D) than Chain Yogic Exercise (Yogasana).

\section{Conclusions}

Chain Yogic Exercise (Yogasana) and Yogic Therapy (Agnisar Kriya) as the yoga intervention is very effective techniques for the T2D patients to control the Fasting \& PP Blood Glucose Level with 90 days practice schedule. In both technique Yogic Therapy (Agnisar Kriya) finds better than the Chain Yogic Exercise (Yogasana) after 90 days practice. Chain Yogic Exercise (Yogasana) and Yogic Therapy (Agnisar Kriya) are very effective techniques for the T2D patients for the betterment of well-being. Hence, we conclude that Chain Yogic Exercise (Yogasana) and Yogic Therapy (Agnisar Kriya) both are good for T2D patients, when both practices continuously for long time period but Yogic Therapy (Agnisar Kriya) is very effective to control T2D.

\section{Conflict of Interest Statement}

The author declares no conflicts of interests.

\section{About the Author}

Amit Chandra Deshmukh was born in East Champaran, India in 1982. He is a Doctoral student in Shanghai Sports University of Sports from the Department of Sports Coaching and Training (2018-2021). He has 15 years teaching working experience, also has double master degree. Current research interest in special rehabilitation therapy for anxiety, depression \& other daily life problem in sportsman and human beings.

Li Youqiang was born in Heilongjiang province, China in 1979. He is a Professor at Shanghai University of Sport at School of Physical Education and Sports Training. He has 10 years of teaching \& research experience. More than 30 of his research articles have been published in different research publications. Currently prof. Li's research interest is health promotion. 


\section{References}

1. McLaughlin, Emily. “Data Collection.” SearchCIO. TechTarget, 2017. https://searchcio.techtarget.com/definition/data-collection.

2. Kapil, H.K., Anusandhan Vidhiya (Agra : Rakhi Prakashan, 2015), PP. 220

3. McLaughlin, Emily. "Data Collection." SearchCIO. TechTarget, 2017. https://searchcio.techtarget.com/definition/data-collection.

4. Kumar, Ranjeet, Research Methodology (London : SAGE Publications Ltd., 2011), PP 131

5. Kothari, C. R., Research Methodology (New Delhi : New Age Internation (P) Ltd., Publishers, 2004), PP. 160.

6. Kapil, H. K., Anusandhan Vidhiya (Agra : Rakhi Prakashan, 2015), PP. 94.

7. Kothari, C. R., Research Methodology (New Delhi : New Age Internation (P) Ltd., Publishers, 2004), PP. 160.

8. Nihal Thomas, A Practical Guide to Diabetes Mellitus, (New Delhi, Jaypee Brothers Medical Publishers (P) Ltd, 2016), PP. xvii

9. WHO Expert Committee on Diabetes Mellitus. Second Report. Geneva: WHO, 1980. Technical Report Series 646.

10. National Diabetes Data Group. Classification and diagnosis of diabetes mellitus and other categories of glucose intolerance. Diabetes 1979; 28: 1039-57.

11. World Health Organization. Diabetes Mellitus: Report of a WHO Study Group. Geneva: WHO, 1985. Technical Report Series 727.

12. Report of a WHO Consultation, Definition, Diagnosis and Classification of Diabetes Mellitus and its Complications (Geneva : World Health Organization, Department of Noncommunicable Disease Surveillance), PP. 1.

13. Agarwal Parmanand, Diabetes and Its Management (Mumbai: Kaivalyadhama, 2009) PP 16

14. Report of a WHO Consultation, Definition, Diagnosis and Classification of Diabetes Mellitus and its Complications (Geneva : World Health Organization, Department of Noncommunicable Disease Surveillance), PP. 2.

15. Jain, Suneel M, Madhumeh, A New Life Partnet (Bhopal: Manjul Publishing House Pvt. Ltd., 2012), PP. 13.

16. Agarwal Parmanand, Diabetes and Its Management (Mumbai: Kaivalyadhama, 2009) PP 16

17. McCance D. R., Hanson R. L., Charles M. A., Jacobsson L. T. H., Pettitt D. J., Bennett P. H. et al. Comparison of tests for glycated haemoglobin and fasting and two hour plasma glucose concentrations as diagnostic methods for diabetes. BMJ 1994; 308: 1323-28. 

be applied to their work. Under the terms of this license, no permission is required from the author(s) or publisher for members of the community to copy, distribute, transmit or adapt the article content, providing a proper, prominent and unambiguous attribution to the authors in a manner that makes clear that the materials are being reused under permission of a Creative Commons License. Views, opinions and conclusions expressed in this research article are views, opinions and conclusions of the author(s). Open Access Publishing Group and European Journal of Physical Education and Sport Science shall not be responsible or answerable for any loss, damage or liability caused in relation to/arising out of conflict of interests, copyright violations and inappropriate or inaccurate use of any kind content related or integrated on the research work. All the published works are meeting the Open Access Publishing requirements and can be freely accessed, shared, modified, distributed and used in educational, commercial and non-commercial purposes under a Creative Commons attribution 4.0 International License (CC BY 4.0). 